\title{
Pathogen-specific risk of chronic gastrointestinal disorders following bacterial causes of foodborne illness
}

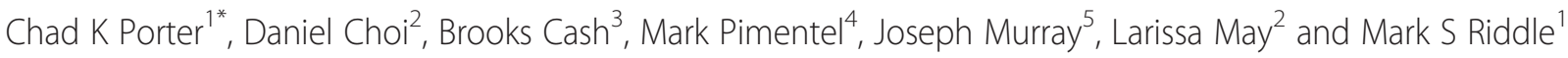

\begin{abstract}
Background: The US CDC estimates over 2 million foodborne illnesses are annually caused by 4 major enteropathogens: non-typhoid Salmonella spp., Campylobacter spp., Shigella spp. and Yersinia enterocoltica. While data suggest a number of costly and morbid chronic sequelae associated with these infections, pathogen-specific risk estimates are lacking. We utilized a US Department of Defense medical encounter database to evaluate the risk of several gastrointestinal disorders following select foodborne infections.

Methods: We identified subjects with acute gastroenteritis between 1998 to 2009 attributed to Salmonella (nontyphoidal) spp., Shigella spp., Campylobacter spp. or Yersinia enterocolitica and matched each with up to 4 unexposed subjects. Medical history was analyzed for the duration of military service time (or a minimum of 1 year) to assess for incident chronic gastrointestinal disorders. Relative risks were calculated using modified Poisson regression while controlling for the effect of covariates.
\end{abstract}

Results: A total of 1,753 pathogen-specific gastroenteritis cases (Campylobacter: 738, Salmonella: 624, Shigella: 376, Yersinia: 17) were identified and followed for a median of 3.8 years. The incidence (per 100,000 person-years) of PI sequelae among exposed was as follows: irritable bowel syndrome (IBS), 3.0; dyspepsia, 1.8; constipation, 3.9; gastroesophageal reflux disease (GERD), 9.7. In multivariate analyses, we found pathogen-specific increased risk of IBS, dyspepsia, constipation and GERD.

Conclusions: These data confirm previous studies demonstrating risk of chronic gastrointestinal sequelae following bacterial enteric infections and highlight additional preventable burden of disease which may inform better food security policies and practices, and prompt further research into pathogenic mechanisms.

\section{Background}

Infectious gastroenteritis (IGE) is caused by a myriad of viruses, bacteria and parasites. Approximately 47.8 million foodborne-related illnesses occur annually in the United States, costing upwards of $\$ 150$ million to the healthcare economy [1,2]. The four major bacterial enteropathogens responsible for morbidity and mortality include non-typhoidal Salmonella, Campylobacter, Shigella, and Yersinia enterocolitica [2]. In addition to the significant burden of the acute illness associated with these infections, recent evidence suggests that these pathogens are linked with chronic health sequelae,

\footnotetext{
* Correspondence: chad.porter@med.navy.mil

'Enteric Diseases Department, Naval Medical Research Center, Silver Spring, MD, USA

Full list of author information is available at the end of the article
}

including functional gastrointestinal disorders (FGD) such as irritable bowel syndrome (IBS), functional constipation, and functional dyspepsia [3-8]. As a heterogeneous complex of disorders, FGD account for approximately $50 \%$ of all visits to gastroenterology practices and result in significant morbidity in the affected patient $[9,10]$. Additionally, these disorders result in significant financial burden, with annual costs per case ranging from $\$ 1,000-\$ 5000$ in the US [11-16]. Furthermore, such infections have been associated with inflammatory bowel disease [17-19], celiac disease [20,21], and functional dyspepsia [3,22-24] which share symptom overlap with gastroesophageal reflux disease (GERD) [25].

While numerous studies have reported on postinfectious FGD (PI-FGD), studies of pathogen-specific associations are limited. Such data are important,

\section{Biomed Central}


considering the need to account for food-borne illness risks in order to develop mitigating policies and practices, as well as to understand pathogenic mechanisms of PI-FGD. Thus, we sought to evaluate the risk of select chronic gastrointestinal consequences following illness attributed to non-typhoid Salmonella, Campylobacter, Shigella, and Yersinia enterocolitica in a young, predominately healthy subset of the US population.

\section{Methods}

This was a retrospective cohort study in which the medical records of subjects diagnosed with non-typhoidal Salmonella spp., Shigella spp., Campylobacter spp., or Yersinia enterocolitica were assessed with the onset of FGD and GERD. Data were obtained from the Armed Forces Health Surveillance Center (AFHSC), which oversees the Defense Department Medical Surveillance System (DMSS), the main data repository for all medical encounters of active duty US military personnel.

Medical encounter history on all subjects with an inpatient or outpatient visit in which one of the following (International Classification of Diseases, $9^{\text {th }}$ Revision) ICD-9 codes were assigned was obtained: Salmonella (003.0 and 003.9), Shigella (004), Campylobacter (008.43) and Yersinia enterocolitica (008.44). Subjects with one of the foodborne illnesses identified above were matched by age, gender, number of deployments, medical treatment facility, encounter type (inpatient, outpatient) and time, to up to 4 subjects without a documented gastrointestinal infection. Baseline diagnoses of unexposed subjects included: acute respiratory infections, pneumonia and influenza, infections of skin and subcutaneous tissue, dislocations, sprains and strains for joints and adjacent muscles, superficial injury, burns, and fracture of the upper or lower limb.

Incident FGD and GERD were similarly identified using medical encounters with specific ICD-9 codes in any diagnostic position as follows: constipation (656.0), irritable bowel syndrome (564.1, 306.4), dyspepsia (536.8), and GERD (530.81). Other covariates obtained included race, military rank, socioeconomic factors (level of education, marital status), and Axis I and Axis II psychological conditions. All subjects with antecedent FGD or GERD diagnoses were excluded.

A modified Poisson regression analysis was used for data analysis with a robust sandwich estimator for variance [26]. Associations were initially explored by univariate methods. Multivariate models were utilized to assess the association between foodborne illness and FGD while controlling for important covariates. Initial models were developed utilizing all exposed subjects using a backwards elimination approach with an alpha of 0.15 . Those models were then applied to pathogen-specific exposures. Two-tailed significance was evaluated using an alpha of 0.05. All analyses were performed using SAS 8.2 (Cary, NC).

The study protocol was approved by the Naval Medical Research Center Institutional Review Board (study protocol NMRC.2011.0003) in compliance with all applicable Federal regulations governing the protection of human subjects.

\section{Results}

We identified 1,753 active duty US military personnel diagnosed with one of the four pathogens of interest (Campylobacter: 738, Salmonella: 624, Shigella: 376, Y. enterocolitica: 17) between 1998 and 2009 (Table 1). A total of 6,765 subjects were included in the referent cohort with baseline diagnoses that included respiratory or skin infections, sprains, strains, dislocations and fractures, superficial injuries and burns. In general, the demographics of the study population were representative of the active duty military population in terms of race (68.5\% Caucasian), education (62\% with only a high school education or equivalent), branch of service (31.1\% Navy, 27.3\% Army, 26.7\% Air Force, 10.1\% Marines, and $4.7 \%$ Coast Guard), rank (81.7\% enlisted), and marital status (69\% married). However, a higher proportion of Navy personnel were included in the referent cohort than in subjects with documented bacterial gastroenteritis $(34.5 \%$ and $17.8 \%$, respectively; $\mathrm{p}<0.001)$. The median follow-up duration was 3.8 (interquartile range [IQR]: 2.1, 6.7) years, totaling 38,844 person-years of observation. A greater proportion of exposed Army personnel had bacterial IGE during the study period (45.0\% for those exposed compared to $2.4-27.7 \%$ for the other branches of service, respectively; $\mathrm{p}<0.001)$.

The most common outcome was GERD $(n=943)$ followed by functional constipation $(n=373)$, IBS $(\mathrm{n}=203)$ and dyspepsia $(\mathrm{n}=190)$. The incidence (per 100,000 person-years) of each of these outcomes stratified by exposure is shown in Table 2. We saw a consistently higher incidence of FGD and GERD for those with prior IGE compared to the referent cohort. The strongest association was for IBS with $Y$. enterocolitica demonstrating the greatest relative risk (aRR: 13.1; 95\% confidence interval [CI]: 4.4, 39.4). Functional dyspepsia showed only a weak association with bacillary diarrhea (Table 3).

We also noted variability in effect estimates across pathogen type. The highest adjusted relative risk for IBS was associated with prior $Y$. enterocolitica infection (aRR: 13.1; 95\% CI: 4.4, 39.4); however, the number of cases was small. $Y$. enterocolitica also conferred significant risk for functional constipation (aRR: 4.4; 95\% CI: 1.2, 15.4). The greatest pathogen variability occurred for the diagnosis of dyspepsia, ranging from an adjusted relative risk of 0.6 for Shigella (95\% CI: $0.2,1.3$ ) to 2.0 
Table 1 Demographics of a cohort of U.S. military service members exposed with bacterial gastroenteritis infections and a matched (age, gender, deployment, baseline medical encounter) cohort of subjects without gastroenteritis

\begin{tabular}{|c|c|c|c|c|c|c|}
\hline & & & Exposed & & & Unexposed \\
\hline & $\begin{array}{c}\text { Any bacillary } \\
\text { diarrhea }\end{array}$ & $\begin{array}{l}\text { Campylobacter } \\
\text { spp. }\end{array}$ & $\begin{array}{l}\text { Non-typhoid Salmonella } \\
\text { spp. }\end{array}$ & $\begin{array}{l}\text { Shigella } \\
\text { spp. }\end{array}$ & $\begin{array}{c}\text { Yersinia } \\
\text { enterocolitica }\end{array}$ & \\
\hline $\mathrm{N}$ & 1753 & 738 & 624 & 376 & 17 & 6765 \\
\hline Median age (IQR) & $28(23,34)$ & $29(24,36)$ & $26(22,32)$ & $29(25,35)$ & $27(23,33)$ & $28(23,34)$ \\
\hline Race $[n(\%)]$ & & & & & & \\
\hline White, Non-Hispanic & $1264(72.1)$ & $584(79.1)$ & $424(68.0)$ & $242(64.4)$ & $16(95.1)$ & $4570(67.6)$ \\
\hline African-American & $275(15.7)$ & $58(7.9)$ & $119(19.1)$ & $97(25.8)$ & $1(5.9)$ & $1291(19.1)$ \\
\hline Other & $214(12.2)$ & $96(13.0)$ & $81(13.0)$ & $37(9.8)$ & $0(0.0)$ & $904(13.4)$ \\
\hline $\operatorname{Sex}[n(\%)]$ & & & & & & \\
\hline Male & $1419(81.0)$ & $624(84.6)$ & $496(79.5)$ & $287(76.3)$ & $14(82.4)$ & $5506(81.4)$ \\
\hline Female & $334(19.1)$ & $114(15.5)$ & $128(20.5)$ & $89(23.7)$ & $3(17.7)$ & 1259 (18.6) \\
\hline $\begin{array}{l}\text { Branch of Service [n } \\
(\%)]\end{array}$ & & & & & & \\
\hline Army & $789(45.0)$ & $378(51.2)$ & $252(40.4)$ & $153(40.7)$ & $8(47.1)$ & $1540(22.8)$ \\
\hline Marine & $124(7.1)$ & $41(5.6)$ & $58(9.3)$ & $23(6.1)$ & $2(11.8)$ & $739(10.9)$ \\
\hline Navy & $312(17.8)$ & $106(14.4)$ & $136(21.8)$ & $68(18.1)$ & $2(11.8)$ & $2336(34.5)$ \\
\hline Air Force & $486(27.7)$ & $204(27.6)$ & $152(24.4)$ & $125(33.2)$ & $5(29.4)$ & $1790(26.5)$ \\
\hline Coast Guard & $42(2.4)$ & $9(1.2)$ & $26(4.2)$ & $7(1.9)$ & $0(0.0)$ & $360(5.3)$ \\
\hline Education [n (\%)] & & & & & & \\
\hline No High School & $12(0.7)$ & $2(0.3)$ & $5(0.8)$ & $5(1.3)$ & $0(0.0)$ & $36(0.5)$ \\
\hline High School & $961(54.9)$ & $357(48.4)$ & $378(60.6)$ & $213(56.7)$ & $14(82.4)$ & $4272(63.2)$ \\
\hline $\begin{array}{l}\text { Less than } 4 \text { yrs of } \\
\text { College }\end{array}$ & $228(13.0)$ & $99(13.4)$ & $79(12.7)$ & 51 (13.6) & $0(0.0)$ & $731(10.8)$ \\
\hline Bachelor's Degree & $257(14.7)$ & $121(16.4)$ & $84(13.5)$ & $51(13.5)$ & $1(5.9)$ & $819(12.1)$ \\
\hline Graduate Degree & $234(13.4)$ & $135(18.3)$ & $54(8.7)$ & $44(11.7)$ & $1(5.9)$ & $628(9.3)$ \\
\hline Unknown & $61(3.5)$ & $24(3.3)$ & $24(3.9)$ & $12(3.2)$ & $1(5.9)$ & $279(4.1)$ \\
\hline Marital Status [n (\%)] & & & & & & \\
\hline Single, Never Married & $347(19.8)$ & $129(17.5)$ & $153(24.5)$ & $61(16.2)$ & $5(29.4)$ & $1892(28.0)$ \\
\hline Married & $1278(72.9)$ & $560(75.9)$ & $429(68.8)$ & $281(74.7)$ & $9(52.9)$ & $4564(67.5)$ \\
\hline Other & $126(7.2)$ & $49(6.6)$ & $41(6.6)$ & $33(8.8)$ & $3(17.7)$ & $309(4.6)$ \\
\hline Unknown & $2(0.1)$ & $0(0.0)$ & $1(0.2)$ & $1(0.3)$ & $0(0.0)$ & $0(0.0)$ \\
\hline
\end{tabular}

for Campylobacter (95\% CI: 1.3, 3.0). In addition, there was a more rapid rate of meeting the case definition, specifically for IBS, across all exposure types (Figure 1).

Across the pathogen-specific exposures, GERD diagnoses commonly overlapped functional GI disorders
(Table 4). This overlap was more common amongst the exposed subjects, where $48.3 \%$ of IBS-diagnosed individuals also received a diagnosis of GERD during their follow-up compared to only $34.2 \%$ in unexposed subjects $(\mathrm{p}=0.04)$. Similarly, amongst exposed subjects with

Table 2 Incidence (95\% confidence interval) of chronic health outcomes per 100,000 person-years in a reference cohort or following documented bacillary diarrhea attributable to Salmonella, Campylobacter, Shigella or Yersinia among active duty U.S. military personnel from 1998 to 2009

\begin{tabular}{lcccccc}
\hline & Any bacterial IGE & Salmonella & Campylobacter & Shigella & Yersinia & Unexposed \\
\hline Irritable bowel syndrome & $3.0(2.5,3.7)$ & $3.1(2.2,4.4)$ & $2.9(2.1,4.0)$ & $2.6(1.6,4.1)$ & $13.2(4.4,39.7)$ & $1.0(0.9,1.2)$ \\
Functional Constipation & $3.9(3.2,4.6)$ & $3.4(2.5,4.7)$ & $4.0(3.0,5.2)$ & $4.2(2.9,6.1)$ & $8.5(2.6,28.0)$ & $2.3(2.1,2.6)$ \\
Functional Dyspepsia & $1.8(1.3,2.3)$ & $1.4(0.9,2.3)$ & $2.6(1.9,3.7)$ & $0.8(0.3,1.8)$ & - & $1.2(1.0,1.5)$ \\
GERD & $9.7(8.6,10.9)$ & $8.4(6.8,10.4)$ & $10.9(9.2,12.9)$ & $9.5(7.4,12.2)$ & $13.9(4.8,40.5)$ & $6.2(5.8,6.7)$ \\
\hline
\end{tabular}


Table 3 Unadjusted and adjusted ${ }^{1}$ relative risk (with $95 \%$ confidence intervals) of chronic health outcomes following documented bacillary diarrhea attributable to Salmonella, Campylobacter, Shigella, and Yersinia among active duty U. S. military personnel from 1998 to 2009

\begin{tabular}{llccccc}
\hline & & All bacterial IGE & Salmonella & Campylobacter & Shigella & \multicolumn{1}{c}{ Yersinia } \\
\hline Unadjusted effect estimates & IBS & $2.9(2.2,3.8)$ & $3.0(2.0,4.4)$ & $2.9(2.0,4.1)$ & $2.5(1.5,4.2)$ & $12.8(4.2,39.3)$ \\
& Functional Dyspepsia & $1.4(1.0,2.0)$ & $1.2(0.7,2.0)$ & $2.1(1.5,3.1)$ & $0.6(0.3,1.5)$ & - \\
& Functional Constipation & $1.7(1.3,2.1)$ & $1.5(1.1,2.1)$ & $1.7(1.3,2.3)$ & $1.8(1.2,2.6)$ & $3.6(1.1,12.1)$ \\
& GERD & $1.6(1.4,1.8)$ & $1.4(1.1,1.7)$ & $1.8(1.5,2.1)$ & $1.5(1.2,2.0)$ & $2.2(0.8,6.5)$ \\
Adjusted effect estimates ${ }^{1}{ }^{2}$ & IBS & $2.7(2.1,3.6)$ & $2.8(1.9,4.2)$ & $2.8(1.9,4.1)$ & $2.3(1.4,3.9)$ & $13.1(4.4,39.4)$ \\
& Functional Dyspepsia & $1.3(1.0,1.9)$ & $1.1(0.6,1.9)$ & $2.0(1.3,3.0)$ & $0.6(0.2,1.3)$ & - \\
& Functional Constipation & $1.6(1.3,2.0)$ & $1.4(1.0,1.9)$ & $1.8(1.3,2.5)$ & $1.6(1.1,2.4)$ & $4.4(1.2,15.4)$ \\
& GERD & $1.6(1.4,1.8)$ & $1.5(1.2,1.8)$ & $1.7(1.4,2.1)$ & $1.5(1.1,1.9)$ & $2.3(0.8,6.9)$ \\
\hline
\end{tabular}

${ }^{1}$ Effect estimates were adjusted for specific covariates as follows:

IBS: branch of military service, ethnicity, gender.

Dyspepsia: marital status, branch of military service, gender, age at initiation of surveillance.

Functional constipation: marital status, military rank, branch of military service, sex, age at initiation of surveillance.

GERD: marital status, military rank, gender.

constipation, 36.5\% were also diagnosed with GERD compared to only $24.8 \%$ who were unexposed $(\mathrm{p}=0.02)$.

\section{Discussion}

Our results support an accumulating body of epidemiological evidence for post bacterial gastroenteritis risk for FGD, including IBS, functional dyspepsia, and constipation, as well as GERD, which to our knowledge is an unrecognized putative sequel of IGE. Similar to prior studies, our results show a significantly increased risk of FGD among those with antecedent bacterial IGE $[3,23,24,27,28]$. Additionally, we observed variability in effect estimates across pathogens. Specifically, we found a greater risk of FGD in those with prior $Y$. enterocolitica infection than what was observed with other bacterial enteropathogens. Prior studies have documented a history of $Y$. enterocolitica infection in adults and children with persistent abdominal pain and other GI complaints [29,30]. In a 2004 follow-up study of laboratory confirmed enteric infections, 9.3\% of survey respondents reported persistent GI symptoms following recovery from acute illness [31]. This proportion was higher for $Y$. enterocolitica (25\%) than for Campylobacter (8.6\%), Salmonella (8.0\%), or Shigella (6.2\%), although the overall response rate was low.

$Y$. enterocolitica is also known to cause granulomatous disease and thus may be a stronger trigger for subsequent immune dysregulation [32]. The association between FGD and antecedent IGE has been reported in several independent studies and systematic reviews [27,33]. In contrast to the published literature, the magnitude of increased risk reported here was lower than prior studies,

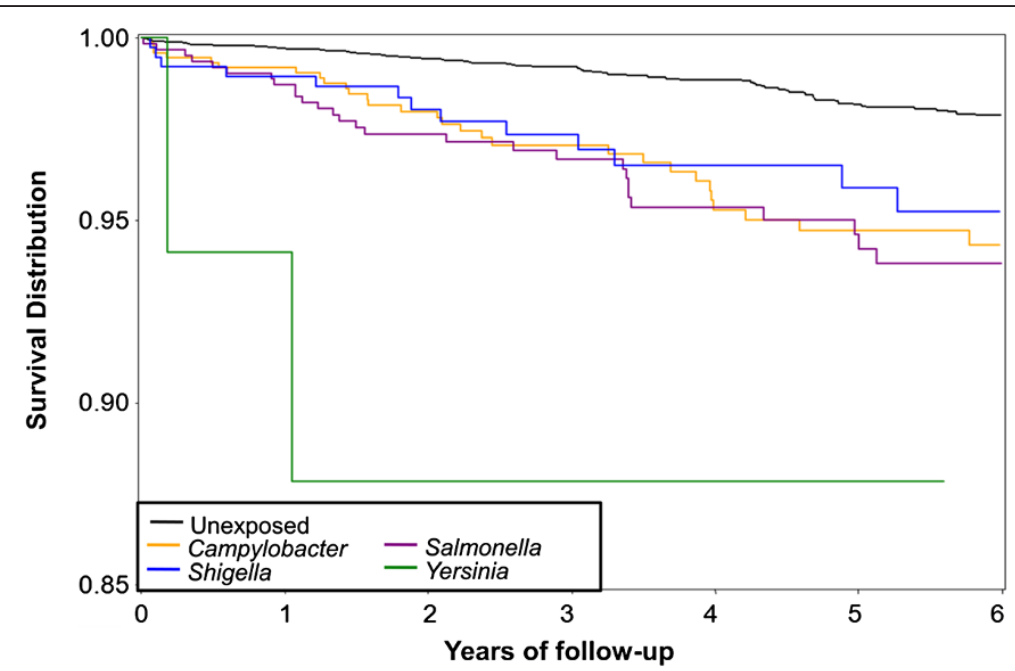

Figure 1 Time to IBS onset following documented bacillary diarrhea attributable to Salmonella, Campylobacter, Shigella, and Yersinia among active duty U.S. military personnel from 1998 to 2009. 
Table 4 Overlap of diagnosed outcomes following documented bacillary diarrhea attributable to Salmonella, Campylobacter, Shigellacpa and Yersinia and an unexposed reference cohort

\begin{tabular}{llcccc}
\hline Cohort & \multicolumn{1}{c}{ Outcome } & IBS & Functional constipation & GERD & Functional dyspepsia \\
\hline Exposed & IBS & $100 \%$ & $22.5 \%$ & $48.3 \%$ & $11.2 \%$ \\
& Functional Constipation & - & $100 \%$ & $36.5 \%$ & $10.4 \%$ \\
& GERD & - & - & $100 \%$ & $11.6 \%$ \\
Unexposed & IBS & $100 \%$ & $21.1 \%$ & $34.2 \%$ & $10.5 \%$ \\
& Functional Constipation & - & $100 \%$ & $24.8 \%$ & $7.4 \%$ \\
& GERD & - & - & $100 \%$ & $11.5 \%$ \\
\hline
\end{tabular}

possibly due to differences in study design and exposure and outcome ascertainment. However, this is the first study to report variable pathogen-specific risks across four common bacterial enteropathogens in a single population. Variability in the site of infection, method of invasion, and induction of the host immune responses due to these four enteropathogens are all possible contributors to the observed variability [34].

Studies of non-IBS PI-FGD are limited, although there are increasing reports on the risk of functional dyspepsia following acute enteric infection [3,5,23]. We recently reported an increased risk of FGD sequelae following all-cause IGE not limited to specific bacterial etiologies $[6,7]$. While the effect estimates here are lower than previously reported, they are in the same direction, and variability may be due to the pathogens studied, sample population, or other methodological differences. Despite the accumulating evidence linking IGE with functional dyspepsia, studies on the post-infectious risk of GERD are lacking. Thus, our finding of an association of enteric bacterial pathogen exposure with an incident diagnosis of GERD is, to our knowledge, a novel finding requiring further exploration. A complicating factor here is the diagnosis of GERD which can be distinguished by a variety of modalities including therapeutic trial, endoscopy, esophageal acid and motility testing, and gastric emptying studies [35]. Our outcome based on medical encounter ICD9-CM did not allow for verification of cases based on differential diagnostic criteria. Interestingly, our effect estimates of functional dyspepsia and GERD are similar, suggesting diagnostic misclassification of upper gastrointestinal dysfunction, or similar pathoetiological mechanisms resulting in these gastroduodenal disorders.

Also problematic in evaluating causation is the possibility that individuals may have used antacid medications (prescription or over-the-counter) for symptoms preceding their GERD diagnosis, which could have increased susceptibility to IGE and confounded the association between IGE and GERD. Confirmatory studies utilizing better-defined diagnostic criteria, database case-validation methods, and control of concomitant medications are needed.

We noted a significant amount of overlap in many of the outcomes; however, overlaps appeared to be more frequent among subjects with an antecedent bacillary diarrhea compared with those who were unexposed. Prior studies on post-infectious IBS following gastroenteritis attributed to non-typhoid Salmonella have pointed to an overlap with dyspepsia [23] and an increased risk of PI-dyspepsia has been reported following numerous IGE exposures [3,6-8,24,36]. While FGDs are often characterized by the Rome criteria [37], such classification may be insufficient at characterizing the true phenotypic classification and symptom complex seen in patients with PI-FGD. Future studies to better characterize the outcome of PI-FGD are needed to expand the phenotypic attributes of these functional outcomes following IGE.

A number of clinical features have previously been shown to be risk modifiers for PI-FGD including severity of disease, sex, use of antibiotics, psychological comorbidities, acute stress, and duration of illness [38-40]. The medical encounter data utilized precluded any clinical symptom-based severity of disease assessment, however we did not identify sex as an important covariate across the FGD models. Furthermore, we were also able to evaluate the potential influence of comorbid psychological conditions on both host susceptibility to enteric infection, as well as the potentiation of FGD after enteric infection. No association between diagnosed psychological disorders and FGD risk in this study was identified (data not shown), possibly due to the reliance on diagnosed mental health conditions instead of self-reported conditions. Several prior studies have identified an association between stressful events prior to infectious episodes and the subsequent risk of FGD [41,42]. However, we were unable to assess undiagnosed stressors or other psychosocial comorbidities prior to either exposure or outcome.

Interpretation of these results should be done with a full appreciation of potential biases inherent with medical encounter database studies, as well as the population under study. Active duty military personnel are younger and generally healthier than other adults, therefore the associations and effect estimates may not be generalizable to other populations. Secondly, because we relied on ICD-9 codes and reportable disease notification data rather than actual laboratory confirmation, we cannot 
assume that IGE was laboratory-confirmed in all cases, although presumably a pathogen-specific ICD-9 would not be coded without confirmation. Because our data set did not include pharmacy data or survey-based symptom assessment, we could not completely control for preexisting functional symptoms, nor the use of proton pump inhibitors, antacids, or other medications, which may have confounded the observed associations with both exposure and outcomes [43]. An attempt was made to control for diagnosed medical conditions in which acid suppressive medication would be used (e.g. peptic ulcer disease, Barrett's esophagus); however, future studies are needed to control for actual medication usage and pre-existing conditions. Similarly, the use of antibiotics for IGE treatment may have increased exposed subjects' risk of FGDs; which, as previously described, may be confounded by subjects with more severe clinical illness [40].

\section{Conclusions}

Despite the noted limitations, we have confirmed an increased risk of FGDs following infection with unique bacterial enteropathogens. Recent reports on the significant costs and morbidity associated with the acute disease attributable to foodborne illness [44,45], and the significant costs and decrements in health-related quality of life associated with the long-term health outcomes reported here $[11,12,15,16,46]$, highlight the need for continued efforts to improve primary prevention strategies and to better understand the etiology underlying the differential pathogen-specific risks. While additional study is needed, these results raise the specter of the potential burden associated with these infections, and highlight the need for primary prevention strategies and optimized food safety policies in the US and globally.

\section{Consent}

This study was conducted using a waiver of informed consent.

\section{Competing interests}

The authors have no competing interest.

\section{Authors' contributions}

CKP and MSR conceived of the study and CKP, DC and MSR carried out all descriptive and statistical analyses and drafted and edited the manuscript. $B C, M P, J M$ and $L M$ participated in its design and coordination and helped to draft the manuscript. All authors read and approved the final manuscript.

\section{Authors' information}

Authors are employees of the U.S. Government and military service members. This work was prepared as part of official duties. Title 17 U.S.C. $\S 105$ provides that 'Copyright protection under this title is not available for any work of the United States Government.' Title 17 U.S.C. \$101 defines a U. S. Government work as a work prepared by a military service member or employee of the U.S. Government as part of that person's official duties.

\section{Acknowledgments}

The authors would like to thank the staff of the Armed Forces Health Surveillance Center for assistance in protocol development and data compilation.

\section{Disclaimer}

The views expressed in this article are those of the author and do not necessarily reflect the official policy or position of the Department of the Navy, Department of Defense, nor the U.S. Government. This is a US Government work. There are no restrictions on its use. There were no financial conflicts of interests among any of the authors. This study was conducted under support of the Military Infectious Disease Research Program.

\section{Author details}

${ }^{1}$ Enteric Diseases Department, Naval Medical Research Center, Silver Spring, MD, USA. ${ }^{2}$ George Washington University, Washington, DC, USA. ${ }^{3}$ Walter Reed National Military Medical Center, Bethesda, MD, USA. ${ }^{4}$ Cedars-Sinai Medical Center, Los Angeles, CA, USA. ${ }^{5}$ Mayo Clinic, Rochester, MN, USA.

Received: 11 October 2012 Accepted: 1 March 2013

Published: 8 March 2013

\section{References}

1. Scallan E, Griffin PM, Angulo FJ, Tauxe RV, Hoekstra RM: Foodborne illness acquired in the United States-unspecified agents. Emerg Infect Dis 2011, 17(1):16-22.

2. Scallan E, Hoekstra RM, Angulo FJ, Tauxe RV, Widdowson MA, Roy SL, Jones $J$, Griffin PM: Foodborne illness acquired in the United States-major pathogens. Emerg Infect Dis 2011, 17(1):7-15.

3. Ford AC, Thabane M, Collins SM, Moayyedi P, Garg AX, Clark WF, Marshall JK: Prevalence of uninvestigated dyspepsia 8 years after a large waterborne outbreak of bacterial dysentery: a cohort study. Gastroenterology 2010, 138(5):1727-1736. quiz e1712.

4. Mearin F: Postinfectious functional gastrointestinal disorders. J Clin Gastroenterol 2011, 45(Suppl):S102-S105.

5. Mearin F, Perello A, Balboa A, Perona M, Sans M, Salas A, Angulo S, Lloreta J, Benasayag R, Garcia-Gonzalez MA, et al: Pathogenic mechanisms of postinfectious functional gastrointestinal disorders: results 3 years after gastroenteritis. Scand J Gastroenterol 2009, 44(10):1173-1185.

6. Porter CK, Gloor K, Cash BD, Riddle MS: Risk of functional gastrointestinal disorders in U.S. military following self-reported diarrhea and vomiting during deployment. Dig Dis Sci 2011, 56(11):3262-3269.

7. Porter CK, Gormley R, Tribble DR, Cash BD, Riddle MS: The incidence and gastrointestinal infectious risk of functional gastrointestinal disorders in a healthy US adult population. Am J Gastroenterol 2011, 106(1):130-138.

8. Tuteja AK, Talley NJ, Gelman SS, Alder SC, Thompson C, Tolman K, Hale DC Development of functional diarrhea, constipation, irritable bowel syndrome, and dyspepsia during and after traveling outside the USA. Dig Dis Sci 2008, 53(1):271-276.

9. Locke GR 3rd: The epidemiology of functional gastrointestinal disorders in North America. Gastroenterol Clin North Am 1996, 25(1):1-19.

10. Chang L: Review article: epidemiology and quality of life in functional gastrointestinal disorders. Aliment Pharmacol Ther 2004, 20(Suppl 7):31-39.

11. Brook RA, Kleinman NL, Choung RS, Melkonian AK, Smeeding JE, Talley NJ: Functional dyspepsia impacts absenteeism and direct and indirect costs. Clin Gastroenterol Hepatol 2010, 8(6):498-503.

12. Brook RA, Kleinman NL, Choung RS, Smeeding JE, Talley NJ: Excess comorbidity prevalence and cost associated with functional dyspepsia in an employed population. Dig Dis Sci 2012, 57(1):109-118.

13. Choung RS, Branda ME, Chitkara D, Shah ND, Katusic SK, Locke GR 3rd Talley NJ: Longitudinal direct medical costs associated with constipation in women. Aliment Pharmacol Ther 2011, 33(2):251-260.

14. Choung RS, Shah ND, Chitkara D, Branda ME, Van Tilburg MA, Whitehead WE, Katusic SK, Locke GR 3rd, Talley NJ: Direct medical costs of constipation from childhood to early adulthood: a population-based birth cohort study. J Pediatr Gastroenterol Nutr 2011, 52(1):47-54.

15. Leong SA, Barghout V, Birnbaum HG, Thibeault CE, Ben-Hamadi R, Frech F, Ofman JJ: The economic consequences of irritable bowel syndrome: a US employer perspective. Arch Intern Med 2003, 163(8):929-935. 
16. Levy RL, Von Korff M, Whitehead WE, Stang $P$, Saunders $K$, Jhingran $P$, Barghout V, Feld AD: Costs of care for irritable bowel syndrome patients in a health maintenance organization. Am J Gastroentero/ 2001, 96(11):3122-3129.

17. Garcia Rodriguez LA, Ruigomez A, Panes J: Acute gastroenteritis is followed by an increased risk of inflammatory bowel disease. Gastroenterology 2006, 130(6):1588-1594.

18. Gradel KO, Nielsen HL, Schonheyder HC, Ejlertsen T, Kristensen B, Nielsen H: Increased short- and long-term risk of inflammatory bowel disease after salmonella or campylobacter gastroenteritis. Gastroenterology 2009, 137(2):495-501.

19. Porter CK, Tribble DR, Aliaga PA, Halvorson HA, Riddle MS: Infectious gastroenteritis and risk of developing inflammatory bowel disease. Gastroenterology 2008, 135(3):781-786.

20. Falth-Magnusson K, Franzen L, Jansson G, Laurin P, Stenhammar L: Infant feeding history shows distinct differences between Swedish celiac and reference children. Pediatr Allergy Immunol 1996, 7(1):1-5.

21. Verdu EF, Mauro M, Bourgeois J, Armstrong D: Clinical onset of celiac disease after an episode of Campylobacter jejuni enteritis. Can J Gastroenterol 2007, 21(7):453-455.

22. Dizdar $\mathrm{V}$, Gilja OH, Hausken $\mathrm{T}$ : Increased visceral sensitivity in Giardiainduced postinfectious irritable bowel syndrome and functional dyspepsia. Effect of the 5HT3-antagonist ondansetron. Neurogastroenterol Motil 2007, 19(12):977-982.

23. Mearin F, Perez-Oliveras M, Perello A, Vinyet J, Ibanez A, Coderch J, Perona M: Dyspepsia and irritable bowel syndrome after a Salmonella gastroenteritis outbreak: one-year follow-up cohort study. Gastroenterology 2005, 129(1):98-104.

24. Parry SD, Stansfield R, Jelley D, Gregory W, Phillips E, Barton JR, Welfare MR Does bacterial gastroenteritis predispose people to functional gastrointestinal disorders? A prospective, community-based, casecontrol study. Am J Gastroenterol 2003, 98(9):1970-1975.

25. Choung RS, Locke GR 3rd, Schleck CD, Zinsmeister AR, Talley NJ, 3: Overlap of dyspepsia and gastroesophageal reflux in the general population: one disease or distinct entities? Neurogastroenterol Motil 2012, 24:229-234. e106.

26. Zou G: A modified poisson regression approach to prospective studies with binary data. Am J Epidemiol 2004, 159(7):702-706.

27. Halvorson HA, Schlett CD, Riddle MS, 8: Postinfectious irritable bowel syndrome--a meta-analysis. Am J Gastroenterol 2006, 101:1894-1899. quiz 1942.

28. Ternhag A, Torner A, Svensson A, Ekdahl K, Giesecke J: Short- and longterm effects of bacterial gastrointestinal infections. Emerg Infect Dis 2008 , 14(1):143-148

29. Gijsbers CF, Benninga M, Buller H: Clinical and laboratory findings in 220 children with recurrent abdominal pain. Acta Paediatr 2011, 100(7):1028-1032.

30. Saebo A, Lassen J: Acute and chronic gastrointestinal manifestations associated with Yersinia enterocolitica infection. A Norwegian 10-year follow-up study on 458 hospitalized patients. Ann Surg 1992, 215(3):250-255.

31. Rees JR, Pannier MA, McNees A, Shallow S, Angulo FJ, Vugia DJ: Persistent diarrhea, arthritis, and other complications of enteric infections: a pilot survey based on California FoodNet surveillance, 1998-1999. Clin Infect Dis 2004, 38(Suppl 3):S311-S317.

32. Lamps LW, Madhusudhan KT, Greenson JK, Pierce RH, Massoll NA, Chiles MC, Dean PJ, Scott MA: The role of Yersinia enterocolitica and Yersinia pseudotuberculosis in granulomatous appendicitis: a histologic and molecular study. Am J Surg Pathol 2001, 25(4):508-515.

33. Thabane M, Kottachchi DT, Marshall JK: Systematic review and metaanalysis: the incidence and prognosis of post-infectious irritable bowel syndrome. Aliment Pharmacol Ther 2007, 26(4):535-544

34. Talley NJ: A unifying hypothesis for the functional gastrointestinal disorders: really multiple diseases or one irritable gut? Rev Gastroenterol Disord 2006, 6(2):72-78.

35. Oustamanolakis P, Tack J: Dyspepsia: organic versus functional. J Clin Gastroenterol 2012, 46(3):175-190.

36. Trivedi KH, Schlett CD, Tribble DR, Monteville MR, Sanders JW, Riddle MS: The impact of post-infectious functional gastrointestinal disorders and symptoms on the health-related quality of life of US military personnel returning from deployment to the Middle East. Dig Dis Sci 2011, 56(12):3602-3609.

37. Thabane M, Marshall JK: Post-infectious irritable bowel syndrome. World J Gastroenterol 2009, 15(29):3591-3596.

38. Thabane M, Simunovic M, Akhtar-Danesh N, Garg AX, Clark WF, Collins SM, Salvadori M, Marshall JK: An outbreak of acute bacterial gastroenteritis is associated with an increased incidence of irritable bowel syndrome in children. Am J Gastroenterol 2010, 105(4):933-939.

39. Gwee KA, Graham JC, MCKendrick MW, Collins SM, Marshall JS, Walters SJ, Read NW: Psychometric scores and persistence of irritable bowel after infectious diarrhoea. Lancet 1996, 347(8995):150-153.

40. Spiller R, Garsed K: Postinfectious irritable bowel syndrome. Gastroenterology 2009, 136(6):1979-1988.

41. Bennett EJ, Tennant CC, Piesse C, Badcock CA, Kellow JE: Level of chronic life stress predicts clinical outcome in irritable bowel syndrome. Gut 1998, 43(2):256-261.

42. Gwee KA: The many faces of irritable bowel syndrome. Singapore Med J 1999, 40(7):441-442.

43. Bavishi C, Dupont HL: Systematic review: the use of proton pump inhibitors and increased susceptibility to enteric infection. Aliment Pharmacol Ther 2011, 34(11-12):1269-1281.

44. Batz MB, Hoffman SJ, Morris J: Ranking the Risks: The 10 Pathogen-Food Combinations With The Greatest Burden on Public Health.. University of Florida: Emerging Pathogens Institute; 2011.

45. Havelaar AH, Haagsma JA, et al: Disease burden of foodborne pathogens in the Netherlands. Int J Food Microbio/ 2009, 156(3):231-238.

46. Brook RA, Wahlqvist P, Kleinman NL, Wallander MA, Campbell SM, Smeeding JE: Cost of gastro-oesophageal reflux disease to the employer: a perspective from the United States. Aliment Pharmacol Ther 2007 , 26(6):889-898.

doi:10.1186/1471-230X-13-46

Cite this article as: Porter et al.: Pathogen-specific risk of chronic gastrointestinal disorders following bacterial causes of foodborne illness. BMC Gastroenterology 2013 13:46.

\section{Submit your next manuscript to BioMed Central and take full advantage of:}

- Convenient online submission

- Thorough peer review

- No space constraints or color figure charges

- Immediate publication on acceptance

- Inclusion in PubMed, CAS, Scopus and Google Scholar

- Research which is freely available for redistribution 